Volume (3) No. (3) 2020

A Standard-based Evaluation of University English Majors' Reading

Skills

Prof. Dr Antar Abdellah \& Dr. Abdulrahman Olwi

http://dx.doi.org/10.29009/ijres.3.3.6 


\title{
A Standard-based Evaluation of University English Majors' Reading
}

\section{Skills}

\author{
Prof. Dr Antar Abdellah \\ professor of foreign language pedagogy, Taibah University, Saudi Arabia, and South \\ Valley University. Egypt. \\ antar20@aim.com
}

Dr. Abdulrahman Olwi

Assistant professor of language education and the dean of e-learning at Taibah

University. Saudi Arabia

amaolwi@gmail.com

Received in 26th April 2020

Accepted in 1st June 2020

\begin{abstract}
This paper investigates the extent to which a Saudi Arabian university English majors' meet the standards in reading skills and compares the reading proficiency of freshmen and graduates to measure the difference between them that can be attributed to their reading curriculum. The sample of the study consisted of 336 freshmen/graduates and male/female students enrolled in the department of English. It is found that the reading program presented to English majors at the university requires professionals and stakeholders to pay good attention to the important areas where participants showed a drastically low level. Detailed results were obtained based on standards and indicators shed more light on areas where female surpass male students, and vice versa. Recommendations for improving the quality of the reading program were suggested.
\end{abstract}

Keywords: reading comprehension, reading skills, Arab students, Saudi Arabia, English language. 


\section{Introduction}

Research into reading in English as a second or a foreign language has repeatedly shown that reading is not the step-by-step process of building up letters into words, relating written words to their spoken equivalents, and joining words to form sentences. On the contrary, reading is a highly complex interaction between a reader and a text, in which the reader makes sense of the text using both textual and nontextual clues. Reading is, in Goodman's words, "a psychological guessing game. It involves an interaction between thought and language" (1967, p. 127).

Actually, reading is seen as a complicated requirement for other language skills. It is not just a decoding process occurring by moving eyes in specific ways. Rather, reading is a thinking process that aims to understand the writer's message. Thus, a genuine connection exists between the reading material and the reader's prior knowledge. As a result, language teachers are supposed to make it possible for readers to decode the written messages and actively add value to their background by connecting the new and old information, asking questions and predicting forthcoming events ... etc.

Many studies, old and new (e.g., Block (1986) \& Duke and Pearson (2002)), emphasized the role of the language teacher in guiding students to interpret and evaluate the reading texts and to make use of their prior knowledge in reaching meaning. Reading comprehension includes more than just word identification. It corporates classifying, sequencing, and establishing whole-part relationships, comparing and contrasting, determining cause-effect relations, summarizing, hypothesizing and predicting, inferring, and concluding. Whether or no English majors at the university possess these skills is the quest of the present study.

English in Saudi Arabia. English was introduced as a school subject early in the life of Saudi Arabia (Al-Seghayer, 2005) although other researchers claim that English did not exist in the intermediate school before the 1950s (Alamri, 2008 \& AlQahtani, 2010). King Abdulaziz established the new state in 1932 and the first language course was introduced in 1933. "The basic way to English" was the big wave at the time initiated by Charles Ogden's Basic English model (Abdellah, 2013). Although the 
reading component in the language program changed over 80 years, little is thought to have really affected students' abilities. During the 1980s, there was a supplementary reading material in secondary stage schools. However, in the 1990s and until now, such a component is missing and its lack has been proven to be a major cause of university students' low level in reading (Abdellah, 2013).

Aljarf (2007) notices that many Saudi students at different stages attack reading using whole word phonics only. Elementary reading programs in Saudi Arabia clearly focus on word identification. However, students' real needs for these learned words are questioned and unsupported by evidence. In Al Nooh and Mosson-McPherson's study (2013, p. 342) that investigated the effectiveness of reading English teaching techniques currently used in Saudi Arabia, while it was expected that the students are able to read basic notices and instructions, the result of students' self-assessment showed that they could not completely see themselves as readers. After asking students about their own reading difficulties, it was found that $70 \%$ of the students reported the lack of concentration as the greatest problem in reading.

Al-Roomy (2013) and Al-Qahtani (2010) found in their studies, students' English language proficiency especially in reading is still way below the satisfactory. Some researchers (i.e., Al-Hazmi (2003); Bersamina (2009)) found that the method of reading instruction is one of the main reasons for such an issue. They reported that Saudi teachers are less qualified and need more proper training that focuses on application and implementation. Another factor that plays a role in such an issue is the very limited English vocabulary words that Saudi students know. Out of the 5000 most common English words, it was found that they have around 900 words; this clearly limits students' reading ability (Nezami, 2012).

As repeated reports show continuous low level in students' achievement in English among other school subjects (e.g., Al-Jarf (2007), Al-Qahtani (2016), Alsamadani (2011), \& Masadeh (2015) among others), the government established the National Commission for Academic Accreditation and Assessment (NCAAA) in 2004 to act as the body responsible for quality of education in Saudi Arabia. However, as the NCAAA is still developing its policies and guides, no fixed criteria are set yet for 
assessing foreign language proficiency among students in Saudi Arabia. The fact that reading is a basic skill on which other academic skills rely (researching, writing, and presenting) leads to the importance of setting separate detailed standards for assessing reading. The present study is adopting Abdellah's (2013) inventory of reading standards as it was developed for university students in general and English majors in particular. The present study seeks to assess students' reading skills in order to specify the areas that need development and the reliability of the current reading program presented at the department of English.

\section{Context of the present study}

Purpose: The purposes of the study are:

1) To investigate the extent to which this Saudi university English majors' meet the required international standards in reading skills.

2) To compare the reading proficiency of freshmen and graduates to measure the difference between them that can be attributed to their reading curriculum presented in departments of English.

3) To compare the reading proficiency of male and female students whether freshmen or graduates?

\section{Sample of the study}

The sample of the study consisted of 336 students enrolled in the department of English. Of whom, 210 are freshmen and 126 are graduates who are enrolled in the educational diploma program (TEFL). Table (1) shows the description of the sample of the study. It is assumed that male and female Saudi students are different in their reading habits and their approaches to reading skills. That's why, male and female students were targeted in the present study to measure the difference between them on both levels: the freshmen and the graduates. 


$$
\begin{aligned}
& \text { أ.د/ عنتر عبداله \& د/ عبدالرحمن علوي } \\
& \text { المجلد (3) العدد (3) 2020م }
\end{aligned}
$$

Table (1) Sample of the Study

\begin{tabular}{|l|c|c|}
\hline Case & Gender & $\mathbf{N}$ \\
\hline \multirow{3}{*}{ Freshmen } & Male & 110 \\
& Female & 100 \\
\hline \multirow{3}{*}{ Graduates } & Total & 210 \\
\hline \multirow{3}{*}{ Total } & Male & 57 \\
\hline & Female & 69 \\
\hline & Total & 126 \\
\hline
\end{tabular}

\section{Methodology}

A descriptive, comparative approach is employed. We describe the actual achievement of students in a standard-based test, and compare between freshmen and graduates' performance in reading.

\section{Instrument}

A proficiency test in reading was developed based on several TOEFL samples. The items address different standards and the indicators are detailed in the appendices. The test compromised five reading passages of average difficulty. Each passage addressed certain skills. The skills fall into three major categories which constitute the three major standards: reading comprehension, reading interpretation and evaluation, and critical reading and inference. Each of these standards included a number of indicators that specify on the types of expected reading behavior. An inventory of the three main standards, the detailed indicators and description of expected good practice was adapted from Abdellah (2013). The test was validated by a jury of professionals in teaching English as a foreign language and educational psychology in the College of Education. 


\section{Administering the test}

The test was administered on a number of 336 students (210 freshmen and 126 graduates) on 5 April 2018. Students were told that the purpose of the test was assessing their overall reading skills to benefit from the results in developing reading courses in the department of English. Graduates were targeted in order to measure the difference between their achievement and that of freshmen and calculate the difference that can be attributed to the effect of their experience with the reading program they have been through for four years. Instructions of the test were told in English and Arabic to sustain clarity and comprehension. Sheets were scored electronically, and data were analyzed using SPSS.

\section{Results of the study}

The results of this study are presented in three sections: the total score, the score of each standard (3 standards), and the score of each indicator (15 standards). In all sections, two-way ANOVA was run to check the effect of the first variable Student Case (freshmen or graduates), the effect of the second variable Student Gender (male or female), and the effect of the interaction between the total score and these two variables. Thus, the results provide answers to the following questions:

1. Is there a difference in students' scores between freshmen and graduates regardless of student gender?

2. Is there a difference in students' scores between male and female students regardless of student case?

3. Is there an effect of interaction between student case and student gender in terms of the total scores?

\section{First: Overall achievement}

In terms of total scores, Table (2) shows a holistic overview of students' mean scores in each standard and each indicator. A first look at the tables shows that students' achievement in reading skills is quite low in general. Freshmen could not achieve more than 15.89 (male) or 14.98 (female) out of a total of 50. Graduates on the other hand surpassed the freshmen and achieved slightly higher than 50\%; 23.57 (male) or 27 


$$
\text { أ.د / عنتر عبداله \& دم/ عبدالرحمن علوي }
$$

(female) out of 50. Students average scores in each standard and each indicator will be handled in details below.

\begin{tabular}{|c|c|c|c|c|c|}
\hline \multicolumn{2}{|l|}{ Students } & Fresh male & $\begin{array}{l}\text { Fresh } \\
\text { female }\end{array}$ & Grad male & $\begin{array}{l}\text { Grad } \\
\text { female }\end{array}$ \\
\hline \multicolumn{2}{|c|}{ Test total (Mean) } & 15.89 & 14.98 & 23.75 & 27 \\
\hline \multirow{9}{*}{$\begin{array}{c}\text { Standard } 1 \text { mean } \\
\text { total }\end{array}$} & Total & 11.28 & 10.71 & 17.34 & 21.03 \\
\hline & N 1 & 0.72 & 0.92 & 1.44 & 1.75 \\
\hline & $\mathrm{N} 2$ & 0.57 & 0.51 & 0.72 & 0.91 \\
\hline & $\mathrm{N} 3$ & 2.91 & 2.97 & 4.23 & 5.16 \\
\hline & $\mathrm{N} 4$ & 0.45 & 0.37 & 0.88 & 0.87 \\
\hline & N5 & 0.36 & 0.35 & 0.42 & 0.41 \\
\hline & N6 & 1.93 & 1.88 & 2.97 & 3.84 \\
\hline & N7 & 2.36 & 1.99 & 3.24 & 4.29 \\
\hline & N8 & 1.98 & 1.72 & 3.43 & 3.80 \\
\hline \multirow{4}{*}{ Standard 2 total mean } & Total & 2.64 & 2.31 & 3.52 & 3.84 \\
\hline & N9 & 0.57 & 0.51 & 0.94 & 1.20 \\
\hline & N10 & 0.77 & 0.66 & 0.95 & 1.20 \\
\hline & N11 & 1.30 & 1.14 & 1.65 & 1.43 \\
\hline \multirow{5}{*}{ Standard 3 total mean } & Total & 1.92 & 1.78 & 2.90 & 2.27 \\
\hline & $\mathrm{N} 12$ & 1.08 & 0.75 & 1.02 & 0.78 \\
\hline & N13 & 0.22 & 0.21 & 1.18 & 0.36 \\
\hline & N14 & 0.60 & 0.67 & 0.96 & 1.12 \\
\hline & N15 & 0.02 & 0.15 & 0.74 & 0.01 \\
\hline
\end{tabular}

Table (2) Overall Mean Scores of Students

Table (3) shows a significant difference between freshmen and graduates based on the use of two-way ANOVA. A significant difference is noticed between the average scores of graduates and freshmen students favoring those of the formers. Such a significant difference is not noticed between the average scores of both genders; which means that there is no difference between the achievement of male students and female students in reading skills that can be attributed to the difference in gender. The interaction between the case of students (freshmen / graduate) and the gender of students (male / female) shows a slightly significant difference. 
Table 3: Univariate Analysis of Variance: F-Test for Two-Way ANOVA

Tests of Between-Subjects Effects

Dependent Variable: Total

\begin{tabular}{|l|c|c|c|c|c|}
\hline \multicolumn{1}{|c|}{ Source } & $\begin{array}{c}\text { Type III Sum } \\
\text { of Squares }\end{array}$ & df & $\begin{array}{c}\text { Mean } \\
\text { Square }\end{array}$ & F \\
\hline $\begin{array}{l}\text { Corrected } \\
\text { Model }\end{array}$ & $8521.663^{\mathrm{a}}$ & 3 & 2840.554 & 63.150 & .000 \\
\hline Intercept & 130778.277 & 1 & 130778.277 & 2907.39 & .000 \\
\hline Case & 7845.813 & 1 & 7845.813 & 174.424 & .000 \\
\hline Gender & 120.260 & 1 & 120.260 & 2.674 & .103 \\
\hline Case $*$ Gender & 361.889 & 1 & 361.889 & 8.045 & .005 \\
\hline Error & 14933.763 & 332 & 44.981 & & \\
\hline Total & 148157.000 & 336 & & & \\
\hline Corrected Total & 23455.426 & 335 & & \\
\hline
\end{tabular}

a. R Squared $=.363($ Adjusted R Squared $=.358$ )

\section{Second: Differences according to Standards}

For Standard 1 (reading comprehension), using two-way ANOVA, Table (4) shows a significant difference between freshmen and graduates. The difference is significant in favor of the achievement of the graduates. The same significant difference also occurs between male and female students, favoring the achievement of female students. The result is quite expected as graduates have already passed through a long experience in reading instruction as compared to freshmen. Nevertheless, even when graduates are significantly different from freshmen, this does not mean that their achievement is satisfactory. The fact is that they score an average of 17 out of 33 for the first standard which is slightly above $50 \%$. Female graduates, however, seem to surpass their male counterparts as they score an average of 21.7 out of $33(65 \%)$. This also justifies why there is a significant difference that is attributed to gender and favoring female students. We will elaborate on Saudi female students' situation later. 


$$
\begin{aligned}
& \text { أ.د/ عنتر عبداله \& د/ عبدالرحمن علوي } \\
& \text { المجلد (3) العدد (3) 2020م }
\end{aligned}
$$

Table 4: Univariate Analysis of Variance: F-Test for Two-Way ANOVA

Dependent Variable: Total1

\begin{tabular}{|l|c|c|c|c|c|}
\hline & $\begin{array}{c}\text { Type III } \\
\text { Sum of } \\
\text { Squares }\end{array}$ & df & Square & F & Sig. \\
\hline Corrected Model & $5769.300^{\mathrm{a}}$ & 3 & 1923.100 & 64.640 & .000 \\
\hline Intercept & 71822.180 & 1 & 71822.180 & 2414.125 & .000 \\
\hline Case & 5086.805 & 1 & 5086.805 & 170.980 & .000 \\
\hline Gender & 205.347 & 1 & 205.347 & 6.902 & .009 \\
\hline Case $*$ Gender & 337.033 & 1 & 337.033 & 11.329 & .001 \\
\hline Error & 9877.271 & 332 & 29.751 & & \\
\hline Total & 83534.000 & 336 & & & \\
\hline Corrected Total & 15646.571 & 335 & & & \\
\hline
\end{tabular}

a. R Squared $=.369($ Adjusted R Squared $=.363)$

For Standard 2 (evaluative and interpretative reading), using two-way ANOVA,

Table (5) shows a significant difference between freshmen and graduates. The difference is significant in favor of the achievement of the graduates. A significant difference does not occur between male and female students. The result is quite expected as graduates have already passed through a long experience in reading instruction as compared to freshmen. Nevertheless, even when graduates are significantly different from freshmen, this does not mean that their achievement is satisfactory. The fact is that they score an average of $3.6($ male $=3.5$, female $=3.8)$ out of a total of 9 for the second standard which is below 50\%. Female graduates do not seem to surpass their male counterparts in this standard as both are below $50 \%$. We will elaborate on this later. 
Table 5: Univariate Analysis of Variance: F-Test for Two-Way ANOVA Tests of Between-Subjects Effects

Dependent Variable: Total2

\begin{tabular}{|l|c|c|c|c|c|}
\hline \multicolumn{1}{|c|}{ Source } & $\begin{array}{c}\text { Type III Sum } \\
\text { of Squares }\end{array}$ & df & $\begin{array}{c}\text { Mean } \\
\text { Square }\end{array}$ & F \\
\hline Corrected & $125.994^{\mathrm{a}}$ & 3 & 41.998 & 19.244 & .000 \\
\hline Model & 2961.077 & 1 & 2961.077 & 1356.783 & .000 \\
\hline Intercept & 115.458 & 1 & 115.458 & 52.903 & .000 \\
\hline Case & .000 & 1 & .000 & .000 & .993 \\
\hline Gender & 7.801 & 1 & 7.801 & 3.574 & .060 \\
\hline Case $*$ Gender & 724.565 & 332 & 2.182 & & \\
\hline Error & 3744.000 & 336 & & & \\
\hline Total & 850.560 & 335 & & \\
\hline Corrected Total & & & & \\
\hline
\end{tabular}

a. $\mathrm{R}$ Squared $=.148$ (Adjusted R Squared $=.140$ )

For Standard 3 (critical reading), using two-way ANOVA, Table (6) shows a significant difference between freshmen and graduates. The difference is significant in favor of the achievement of the graduates. A significant difference also occurs between male and female students in favor of male students. The result is quite expected as graduates have already passed through a long experience in reading instruction as compared to freshmen. Nevertheless, even when graduates are significantly different from freshmen, this does not mean that their achievement is satisfactory. The fact is that they score an average of $2.5($ male $=2.8$, female $=2.2)$ out of 8 for the third standard which is far below $50 \%$. Male graduates seem to surpass their female counterparts in this standard as they score an average of 2.25 out of 8 (28.8\%) as compared to 1.89 $(23.3 \%)$. We will elaborate on Saudi male and female students' situation later. 


$$
\begin{aligned}
& \text { أ.د/ عنتر عبداله \& د/ عبدالرحمن علوي } \\
& \text { المجلد (3) العدد (3) 2020م }
\end{aligned}
$$

Table 6: Univariate Analysis of Variance: F-Test for Two-Way ANOVA

Tests of Between-Subjects Effects

Dependent Variable: Total3

\begin{tabular}{|l|c|c|c|c|c|}
\hline Source & $\begin{array}{c}\text { Type III Sum } \\
\text { of Squares }\end{array}$ & df & Square & F & Sig. \\
\hline $\begin{array}{l}\text { Corrected } \\
\text { Model }\end{array}$ & $51.913^{\mathrm{a}}$ & 3 & 17.304 & 10.952 & .000 \\
\hline Intercept & 1538.240 & 1 & 1538.240 & 973.569 & .000 \\
\hline Case & 42.375 & 1 & 42.375 & 26.820 & .000 \\
\hline Gender & 11.225 & 1 & 11.225 & 7.104 & .008 \\
\hline Case * Gender & 4.529 & 1 & 4.529 & 2.866 & .091 \\
\hline Error & 524.560 & 332 & 1.580 & & \\
\hline Total & 2081.000 & 336 & & & \\
\hline Corrected Total & 576.473 & 335 & & \\
\hline a. R Squared $=.090$ (Adjusted R Squared $=.082)$ & & \\
\hline
\end{tabular}

Third: Differences according to indicators

Based on table (2) above, table (7) below, and the results of one-way ANOVA, the results for indicators can be summarized as follows:

Indicator (1: Identify main ideas in a text): There is a significant difference in favor of graduates, and a significant difference in favor of female students.

Indicator (2: Recognize organization of ideas): There is a significant difference in favor of graduates, and no significant difference in gender.

Indicator (3: Identify stated details): There is a significant difference in favor of graduates, and a significant difference in favor of female students.

Indicator (4: Identify pronominal referencing): There is a significant difference in favor of graduates, and no significant difference in gender.

Indicator (5: Find definitions from structural clues): There is no significant difference whether in case (freshmen / graduate) nor gender (male / female).

Indicator (6: Identify meaning based on morphological clues): There is a significant difference in favor of graduates, and a significant difference in favor of female students. 
Indicator (7: Identify meaning based on explicit contextual clues): There is a significant difference in favor of graduates, and no significant difference in gender.

Indicator (8: Identify meaning based on implicit contextual clues): There is a significant difference in favor of graduates, and no significant difference in gender.

Indicator (9: Identify facts and opinions): There is a significant difference in favor of graduates, and no significant difference in gender.

Indicator (10: Identify author's implications): There is a significant difference in favor of graduates, and no significant difference in gender.

Indicator (11: Identify turning points in the text): There is a significant difference in favor of graduates, and no significant difference in gender.

Indicator (12: Agree or disagree with the author): There is no significant difference in case (freshmen / graduate), but there is a significant difference in gender in favor of male students.

Indicator (13: Determine tone): There is no significant difference whether in case (freshmen / graduate) nor gender (male- female).

Indicator (14: Determine purpose): There is a significant difference in favor of graduates, and no significant difference in gender.

Indicator (15: Determine where to insert a piece of information): There is a significant difference in favor of graduates, and there is a significant difference in gender in favor of male students. 


$$
\begin{aligned}
& \text { أ.د/ عنتر عبداله \& د/ عبدالرحمن علوي } \\
& \text { المجلد (3) العدد (3) 2020م }
\end{aligned}
$$

Table (7) Difference between Students' Achievement in Each Indicator with Regard to Case

\begin{tabular}{|c|c|c|}
\hline Indicator & $\begin{array}{c}\text { Difference between Freshmen } \\
\text { and Graduates }\end{array}$ & $\begin{array}{c}\text { Difference between Male and Female } \\
\text { Students }\end{array}$ \\
\hline 1 & Yes- for graduates. & Yes- for female \\
\hline 2 & Yes- for graduates. & No. \\
\hline 3 & Yes- for graduates. & Yes- for female \\
\hline 4 & Yes- for graduates. & No. \\
\hline 5 & No. & No. \\
\hline 6 & Yes- for graduates. & Yes- for female \\
\hline 7 & Yes- for graduates. & No. \\
\hline 8 & Yes- for graduates. & No. \\
\hline 9 & Yes- for graduates. & No. \\
\hline 10 & Yes- for graduates. & No. \\
\hline 11 & Yes- for graduates. & No. \\
\hline 12 & No. & Yes- for male \\
\hline 13 & No. & No. \\
\hline 14 & Yes- for graduates. & No. \\
\hline 15 & Yes- for graduates. & Yes- for male \\
\hline
\end{tabular}
and Gender

\section{Discussion}

Based on the attained results described above, we can make the following points:

- English majors at the university have a very low level in reading skills in general. Freshmen could not achieve $50 \%$ of the total mark in the test, which reflects their insufficient training in secondary schools. One reason for such low level of freshmen can be attributed to the lack of training on extensive reading skills in the secondary stage as specified by Abdellah (2013). While freshmen can be excused for falling short of the required reading skills, graduates who have already gone through an intensive program of reading instruction over four years cannot easily be excused. Graduates scored slightly above $50 \%$ of the total mark. This is not what is expected of graduates who are ready to be teachers of English in schools. In fact, it is female graduates 
only who scored above $50 \%$. Male graduates didn't even reach the $50 \%$ level. Two questions need answers here: 1 . Why are graduates having this low level? 2. Which female graduates surpass their male counterparts?

- One answer to the first question can be attributed to the nature of evaluation at the department of English at the university. Since all tests are required to be in the MCQ format, students decline to read lengthy texts and restore to summaries written by peers or teachers. Reluctance to reading extensively, shortage of essay type exams, and the bad reading habits followed by students can all be causes for this low level. Most Saudi students do not read fiction even in Arabic; as they have not been introduced to supplementary readers while in the high school stage, and confine to summaries and notes of lengthy texts (drama, novel, or literary criticism) in the university stage. In fact, these bad reading habits are not specific for Saudi learners; other Arab world studies (e.g., Jraissati (2010), Bendriss and Golkowska (2011), Hanna (2011), AlYacoub (2012), \& Kechichian (2012)) concluded that Arab students of all levels, including Saudis, do not read enough, if any at all. The findings of the present study are also in agreement with Saudi studies (e.g., Rajab and Al-Sadi (2015), Al-Mansour and Al-Shorman (2011), \& Al-Musallam (2009)) that show that Saudi students have a low tendency to read in Arabic and in English. In fact, Al-Nujaidi (2003) found that the majority of Saudi students do not read outside school. One recommendation for the department of English at the university would then be the crucial need to set up a reading club for students to be able to practice light readings of their own choice to foster the inclination to read in prospective students.

- $\quad$ For the second question, it is noticed generally that female students in Saudi Arabia are raised differently from the way male students are raised and educated. For long, female education was not even monitored by the ministry of education. It was rather managed and run by the late presidency for female education. Female students are segregated from male students in all education stages and are taught and served by female teachers and personnel only. When 
there is a shortage of female professors at college, a male professor is asked to teach female students through a closed circuit system in which students would be able to see the teacher but not the other way round, although he can still hear them. This does not normally hinder communication. However, most female students feel that the professor does not identify each one of them separately, so most of them try to make up for this loss by exerting more effort in study. This remark is based on the researchers' long experience of teaching female students in Saudi Arabia. In addition, certain other qualities mark the distinction of female students when it comes to language proficiency. These results coincide with many studies that found differences between males and females in reading, favoring the females over the males (Abdellah (2001), Vadon (2000), Kranzler (1999), McKenna (1997), McCall (1989), Edwards (1989), Hyde \& Linn (1988), Flynn (1983), Day \& Hollingsworth (1983), Yawkey (1980), \& Bewley (1975)). However, most of these studies found that these differences tend to change according to the age and development of students from time to time, and present very different reasons for the superiority of females:

- Females tend to be interested in reading more than males (Edwards, 1989 \& Shannon, 1992).

- Most females as well as males regard reading as a female activity (Valon 2000, McKenna 1997, \& McCall 1989).

- In Thompson's view, "boys tended to rely more than girls of the same reading level on access to phonological segments of words" when using alternative cognitive processes of word reading (1987, p. 212).

- Mazid explains that "females make better language teachers (and learners) may be because language .... is both communication and metacommunication. They try to maintain an exchange and make their interlocutors feel OK" (1995, p. 7).

- Schultheis (1999) concluded that females spend more time reading than males. 
- McCall (1989) declares that girls have been penalized, not rewarded, for verbal skills and have been blamed for creating an atmosphere that contributes to boys' failing. Girls begin to test less well than boys in secondary school even while receiving higher grades.

- Hyde and Linn (1988) indicate a slight female superiority in reading performance, while verbal scores showed superior male performance, and they suggest that these findings should have implications for theories of sex differences in brain lateralization and changing gender roles.

- Lock and Miller (1992) concludes that there is little basis to conclude that gender is particularly favored by explicit, implicit, or extended type reading test items or by the nature of the reading test item passage.

- Detailed results attained based on standards and indicators shed more light on areas where female surpass male students, and vice versa. It is noticed that female surpass male students in standard one only (reading comprehension), and more specifically in indicators 1,3 , and 6 . Indicator one concerns the skill to identify the main idea, indicator 3 is about identifying details, and indicator 6 is about using morphological clues in identifying meaning. It seems that as female students do more free reading then males, they acquire a skill in quickly identifying the gist and locating the details. They tend to have an analytical approach in attacking the text as they look for morphological clues to identify the meaning of unfamiliar words.

- For standard two, no difference is noticed between male and female students. For standard three, surprisingly, male students seem to surpass female students. Now, this looks contradictory; as how come students who couldn't reach a 50\% level in reading comprehension achieve remarkably in more complicated skills like evaluative and critical reading? The fact is that, although there is a significant difference between the two groups, still both achievements are considerably low ( $28 \%$ for male and $23 \%$ for female). Being near to $25 \%$ of the total does not mean that male students are more competent than female students, especially as there are a few number of items for the third standard 


$$
\text { أ.د المجلتر عبداله \& د د/ عبدالرحمن علوي (3) العدد (3) 2020م }
$$

(8 out of 50). A closer look at the indicators shows that this superficial difference is at indicators 12 and 15. Indicator 12 is about agreeing or disagreeing with the author. Indicator 15 is about deciding where to insert a piece of information. Both indicators seem related to decision taking which is normally a characteristic of Arab males personality rather than the hesitant and uncertain personality of most Arab females.

- What is more important, however, is to have a closer look at students' achievement in each indicator so as to locate where exactly they need more training, and what aspects of the reading program need to be paid attention to. The following graph summarizes the results:

\section{Ss' scores in each indicator}

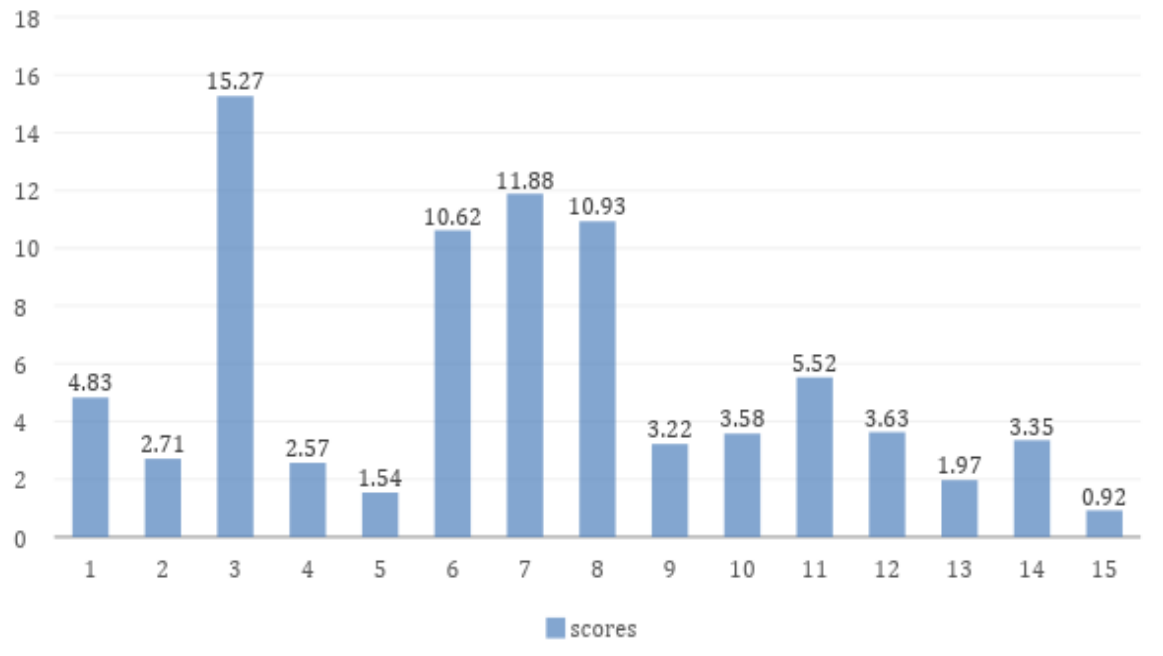

- The graph shows that a special attention should be paid to indicators: 1, 2, 4, $5,9,10,12,13,14$, and 15 when course designers at the department of English at the University decide on changing the reading program presented to their students. These indicators focus on: 
- Indicator one: identifying main idea. Good practice can include identifying the main characters, the main events, the sequence of events, the main places and the main duration of time in the reading passage.

- Indicator two: recognize organization of ideas. Good practice can include determining which paragraph contains which idea, how ideas are connected and where in the text an element (character, place, act) is introduced and where it is repeated.

- Indicator four: Identify pronominal referencing. Good practice can include locating the antecedent to which a pronoun (he, she, they. Him, them, hers, theirs, us ...etc), a demonstrative (this, that, these , those, the other one, the latter, the former, ...etc) or a relative clause (who, which, that, whom, whose..etc) is referring

- Indicator five: Find definitions from structural clues. Good practice can include identifying sentences patterns in a reading text, i.e (statements, questions, commands, requests, instructions, ..etc) -Predicting what kind of words will most likely precede or follow certain other words due to word order. -Indicating kinds of words on the basis of word markers ,i.e (noun markers: articles, possessive pronoun, demonstrative... etc) -Comprehend written materials using punctuation rules, i.e (apostrophes, hyphens, question marks, ... etc)

- Indicator nine: Identify facts and opinions. Good practice can include identifying facts provided with statistical data and cited references from opinions which may include judgmental statements about certain people, places or events unaided with reasonable evidences or proofs.

- Indicator ten: Identify author's implications. Good practice can include identifying what the author meant by using certain expressions or vocabulary items. - Identifying whether the author is approving or disapproving of something or somebody based on the connotations associated with the use of certain words. Identify current issues or dates 
based on reference to past events or dates in the text. i.e. (if a character was born in 1978 this means s/he is 40 years old now).

- Indicator 12: Agree or disagree with the author. Good practice can include: agreeing or disagreeing - based on the opinions and the facts provided by the author- with the ideas mentioned by supporting. - debating and arguing for or against certain issues supporting his/ her argument with proofs and evidences, and identifying contradictions in the text which lead to disagreement by locating where in the text the author is making the contradiction.

- Indicator 13: Determine tone. Good practice can include identifying the feelings and emotions of the author by referring to the types of words and clauses s/he uses.

- Indicator 14: Determine purpose. Identify whether the author is trying to persuade the reader, advocating certain ideas, reporting events, or criticizing certain issues by mocking and satirizing events.

- Indicator 15: Determine where to insert a piece of information. Based on the comprehension gained, a reader can replace the writer / author and modify the reading passage by omitting or adding certain pieces of information to support the issues presented in the text.

\section{Conclusion}

The reading program that is presented to English majors at this Saudi university requires professionals and stakeholders to pay good attention to the important areas where participants of this study showed a drastically low level. It is hoped that the present study shed light for decision makers and be an eye opener for them to cater for the real needs of their students. Until this happens, we remain apprehensive. 


\section{References}

Abdellah. A. (2001). The effect of a suggested program for developing some basic reading skills of Primary stage prospective teachers. MA thesis. South Valley University. College of Education - Egypt.

- Abdellah. A. (2013). Training Saudi English majors in extensive reading to develop their standard-based reading skills. Journal of King Saud University - Languages and Translation (2013) 25, 13-20. http://dx.doi.org/10.1016/j.jksult.2012.12.002

Al Jarf, R. (2004). The effects of web-based learning on struggling EFL college writers. Foreign Language Annals, 37(1), 49 - 57. doi:10.1111/j.19449720.2004.tb02172.x, http://dx.doi.org/ $10.1111 / \mathrm{j} .1944-$ 9720.2004.tb02172.x

- $\quad$ Al Nooh, A. \& Mosson-McPherson, H. (2013). The Effectiveness of Reading Techniques. Arab World English Journal. AWEJ Volume 4.Number. 3, 2013. www.awej.org. ISSN: 2229-9327. 344

Al qahtani, A. (2016). Why Do Saudi EFL Readers Exhibit Poor Reading Abilities?. Journal of English Language and Literature. 6. 1-15. 10.5539/ells.v6n1p1.

- Al-Hazmi, S. H. (2003). EFL teacher preparation programs in Saudi Arabia: Trends and challenges. TESOL Quarterly, 37(2), 341-344. http://dx.doi.org/10.2307/3588509

- $\quad$ Al-Jarf, R. (2007). Developing Reading and Literacy in Saudi Arabia. King Saud University. Riyadh, Saudi Arabia

- $\quad$ Al-Mansour, N. S., \& Al-Shorman, R. E. A. (2011). The effect of teacher's storytelling aloud on the reading comprehension of Saudi elementary stage students. Journal of King Saud University, Languages and Translation, 23(2), 69-76. http://dx.doi.org/10.1016/j.jksult.2011.04.001

- Al-Musallam, E. (2009). College instructors' and learners' attitudes to authentic EFL reading materials in Saudi Arabia (Unpublished doctoral 
dissertation). King Saud University, Saudi Arabia. (PDF) Why Do Saudi EFL Readers Exhibit Poor Reading Abilities?

- Al-Nujaidi, A. (2003). The relationship between vocabulary size, reading strategies, and reading comprehension of EFL learners in Saudi Arabia (Unpublished doctoral dissertation). Oklahoma State University, USA.

- Al-Qahtani, A. (2010). The effectiveness of metacognitive strategies on secondary stage students' achievement and attitudes towards English language (MA thesis). Taif University, Saudi Arabia.

Al-Roomy, M. (2013). An action research study of collaborative strategic reading in English with Saudi medical students ( $\mathrm{PhD}$ thesis). University of Sussex, UK.

- Al-Seghayer, K. (2005). Teaching English in the Kingdom of Saudi Arabia: slowly but steadily hanging. In Braine, G. (Ed.) Teaching English to the world: history, curriculum and Practice. New Jersey: Lawrence Erlbaum Associates, pp.134-135.

Al-Yacoub, I. (2012). Sum of all fears: Arabs read an average of 6 pages a year, study reveals. From Al Arabiya News Online. Retrieved from http://www.alarabiya.net/articles/2012/07/14/226290.html (PDF) Why Do Saudi EFL Readers Exhibit Poor Reading Abilities?

Alamri, A. (2008). An Evaluation of the Sixth Grade English Language. (MA Thesis).

- Alsamadani, H. (2011). Saudi students' awareness of reading strategies and factors affecting their EFL reading comprehension. British Journal of Arts and Social Sciences, 2(2), 75-87. (PDF) Why Do Saudi EFL Readers Exhibit Poor Reading Abilities?

- $\quad$ Bendriss, R. \& Golkowska, K. (2011). Early reading habits and their impact on the reading literacy of Qatari undergraduate students. Arab World English Journal, 2(4), 37-57. (PDF) Why Do Saudi EFL Readers Exhibit Poor Reading Abilities? Available from: 
https://www.researchgate.net/publication/297353697_Why_Do_Saudi_ EFL_Readers_Exhibit_Poor_Reading_Abilities [accessed Sep 18 2018].

- $\quad$ Bersamina, F. V. (2009). English as second language (ESL) learners in Saudi Arabia. Associated Content Society.

- Bewley. L. (1975) "The Effects of Family Structure, Socioeconomic Status, and Pupil Gender upon Children's Reading Readiness Scores.” Ph.D. Dissertation, the University of Oklahoma ERIC_NO: ED119107.

- $\quad$ Block, E. (1986). The comprehension strategies of second language readers. TESOL Quarterly, 20(3), 463-494.

- Day. H. \& Hollingsworth, S. (1983). Gender Differences in the Relationship of Nascent Conservation and Reading Abilities. Journal of Educational Research; v76 n6 p347-50 Jul-Aug 1983.

- Duke N. \& Pearson P. (2002). Effective practices for developing reading comprehension. In Farstrup A. E., Jay Samuels S. (Eds.), What research has to say about reading instruction? (3rd ed.). International Reading Association.

- Edwards. I. (1989). "Sex Differences and Reading Gender.” Master's Thesis, Kean College. ERIC_NO: ED305617. [on-line]. Available: http:// askeric.org/plweb-cgi/fastweb.

- $\quad$ Flynn, E. (1983). Gender and Reading. College English; v45 n3 p236-53.

- Hanna, J. (2011). I read, therefore, I am. Highlights -University of Balamand Student Newspaper, 11.

- $\quad$ Hyde, J. \& Linn, M. (1988). Gender Differences in Verbal Ability: A MetaAnalysis. Paper presented at the Annual Meeting of the American Educational Research Association (New Orleans, LA, April 5-9, 1988).

- Jraissati, Y. (2010). Who said Arabs don't read? Retrieved from http://jraissati.com/2010/10/who-said-arabs-dont-read/

- Kechichian, J. A. (2012). Arab populations don't read enough. Gulf News Newspaper. 
- $\quad$ Kranzler, J. \& Miller, M. (1999). “An Examination of Racial/Ethnic and Gender Bias on Curriculum-Based Measurement of Reading." ERIC_NO: ED435087. [on-line].

- Lock, L. \& Miller, L. (1992) "An Analysis of Gender Differences in Pennsylvania's 1991 Holistic Model Reading Tests." Paper presented at the Annual Meeting of the Pennsylvania Educational Research Association (Philadelphia, PA, February 1992).

- Masadeh, T. (2015). Performance of Saudi English Language Teachers in Reading Comprehension Classes. Journal Article. 2158244015621598.

- Mazid, B. (1995). "Why is EFL female- dominated?” TEFL Educator. Cairo: FulBright, Autumn.

- $\quad$ McCall, C. (1989). "Gender and Reading Assessment." Paper presented at the Annual Meeting of the College Reading Association (33rd, Philadelphia, PA, November 3-5. ERIC_NO: ED320116.[online]. Available: http:// askeric.org/plweb-cgi/fastweb.

- McKenna. E. (1997). Gender Differences in Reading Attitudes. M.A. Project, Kean College of New Jersey.

- Nezami, S. (2012). A critical study of comprehension strategies and general problems in reading skill faced by Arab EFL learners with special reference to Najran University in Saudi Arabia. International Journal of Social Sciences and Education, 2(3), 306-316.

- $\quad$ Rajab, H., \& Al-Sadi, A. (2015). An empirical study of reading habits and interests of Saudi university EFL learners. International Journal of Linguistics, 7(2), 1-17.

- Schultheis. C. (1999). "A Study of the Relationship between Gender and Reading Preferences in Adolescents. M.L.S.” Research Paper. Kent State University.

- Shannon. S. (19982). Sex Differences in School Learning. Journal of Children and Youth. Fall 1982. 
- Thompson. B. (1987). "Three Studies of Predicted Gender Differences in Processes of Word Reading." Journal of Educational Research; v80n4 p212-19 Mar-Apr 1987.

- Vadon, A. (2000). "Gender and Cultural Differences in Attitude toward Reading in an Adult Population." MA Research Project, Kean University.

- Yawkey, T. (1980). "Effects of Social Relationships Curricula and Sex Differences on Reading and Imaginativeness in Young Children" .Alberta Journal of Educational Research; v26 n3 p159-68. 


\section{Authors:}

- Antar Abdellah is a professor of foreign language pedagogy at Taibah University and South Valley University. He taught TESOL in Egypt and Saudi Arabia for more than 20 years. He published a number of research papers on translation, translation pedagogy, linguistics, children's literature, and language assessment. His books include: pedagogies of translation, teaching and researching translation, English Literature made easy, novice translators' guide, novice Writers' guide. He translated 4 books and supervised a big number of MA and PhD students. He can be reached at this email: antar20@aim.com .

- Abdulrahman Olwi is an assistant professor of language education and the dean of e-learning at Taibah University. He got his $\mathrm{PhD}$ from Florida State University and his MA from the University of San Francisco in TESOL. His research interest is in language assessment and language teacher preparation. He has taught methods of teaching English, English language practicum, research methods in foreign language studies, English language skills, language assessment, ESOL in content area,... etc. He can be reached at this email: amaolwi@gmail.com . 
1. أوكيل، سعيد. (2011م). الابتكار التكنولوجي لتحقيق التنمية المستدامة وتعزيز التنافسية،

$$
\text { الرياض: العبيكان للنشر والتوزيع. }
$$

2. بيزز، سيو (2014م) تدريس مهارات القرن الحادي والعشرين أدوات عمل. (ترجمة عممد بلال

$$
\text { الجيوسي): الرياض مكتب التربية العربي لدول الخليج. }
$$

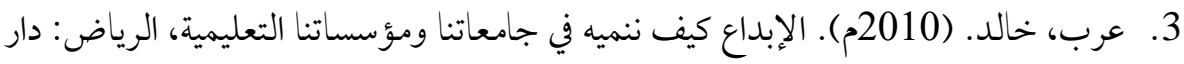

$$
\text { الزهراء. }
$$




\section{References}

- Barak, M.,(2009), Idea Focusing Versus Idea Generating: A Course for Teacher on Inventive Problem Solving, Innovation in Education and Teaching International, Vol.46, No.4.

- Bowyer, D.,(2008), Evaluation of Effectiveness of TRIZ Concepts in NonTechnical Problem Solving Utilizing a Problem Solving Guide Doctoral Dissertation, Pepperdine University.

- Cardellini,L.,(2006), Creative Problem Solving in Chemistry through Group Work, Chemistry Education Research and Practice, Vol.7,No.2..

- Coakes, Elayne, (2003), Knowledge Management: Current Issues and Challenges, Idea Group Publishing, USA.

- $\quad$ Karen Chapple, (2008), Defining the Green Economy: A Primer on Green Economic Development, Center for Community Innovation, University of California, Berkeley.

- Mank, David, (2005), Using Data Mining for E-Learning McGraw-Hill, New York.

- $\quad$ Oana Pop et.al. (2011), Promoting the corporate social responsibility for a green economy and innovative jobs, Science Direct, Procedia Social and Behavioral Sciences, Elselvier,Vol,15. 